\title{
An Investigation into the Study Habits of Distance Learners: Implications for Guidance and Counseling Services
}

\author{
Beatrice Asante Somuah \\ Centre for Continuing Education (Central Regional Office), University of Cape Coast \\ bsomuah@ucc.edu.gh \\ Lydia Aframea Dankyi \\ Centre for Continuing Education (Counselling Unit), University of Cape Coast \\ lydia.larbi@yahoo.com \\ Joyce Kwakyewa Dankyi \\ Centre for Continuing Education (Admissions Unit), University of Cape Coast \\ ebosac@yahoo.com
}

Doi:10.5901/mjss.2014.v5n6p273

\begin{abstract}
This study looked at the study habits of University of Cape Coast Distance Education learners in the Cape Coast Study Centre in the Central Region of Ghana. Descriptive survey design was used to conduct the study. Stratified and simple random sampling procedures were used to select 338 Business and Education distance learners. A self-designed questionnaire, which consisted of 40 items, was used to collect data from the respondents. Data collected was analysed by the use of descriptive (frequencies and percentages). The results of the study revealed that Distance Education students exhibit study habits such as reading while lying in bed, not being able to study for a minimum of three hours in a day, do not look for additional materials from the internet as well as reading over their notes before their next face-to-face meetings. It was found in the study that distance education students need guidance and counselling on time management, prioritizing their daily activities, as well as how to develop effective reading skills. It is therefore recommended that distance education students be provided with guidance and counselling on effective study habits as a support service.
\end{abstract}

Keywords: Distance Education learners, study habits, learning environment, note taking, time management concentration of students, guidance and counselling services

\section{Introduction}

Teaching and learning are very important processes in education. The process can only become successful when teachers fully know their subject matter and effectively communicate it to students and while students have a clear view of their abilities, have good study habits and are able to use effective study skills. Learning how to study involves putting away the habits and ideas which make study unpleasant and burdensome, and taking on habits and ideas which make study more pleasant and fruitful. For a vast number of students, examination times can be quite stressful and frightening. Students want to get the best grades, but what many do not realize is that good grades come easily if the focus is on the passion to learn the subject and not upon grades (Nyarko-Sampson, 2004). Why do some individuals learn more quickly and thoroughly than others? Some of the main reasons for inefficiency in learning could be one's carelessness and ineffective study habits. According to New Standard Dictionary of Education (2001), study habits mean theme setting of subject to be learned or investigated, and the tendency of pupils or students to study when the opportunity is given. Effective and successful study consists of more than merely memorizing of facts. It calls for knowing where and how to obtain important information and ability to make intelligent use of it.

According to Crow and Crow (1992), the effective study habits include plan, place, a definite time table and taking brief or well organized notes. To study successfully, a student must decide what information is important and then form opinions concerning it. All of these must be done to the best of his or her ability in the short possible span of time. Because, knowledge is very important to every person, it is wise to learn how to study in the most effective way. Experts, 
(Bajwa, Gujjar, Shaheen \& Rawzan, 2011), have agreed that great success in the field of knowledge is attributed to good and consistent study habits. Like any other activity, skills and dedication are the key points for learning. Azikiwe (1998) asserted that good study skills are good assets to learners; because, these assets assist students to attain mastery in areas of specialization and consequent excellent performance, while the opposite constitute constraints to learning and achievement leading to failure. Sorenson (1991), while outlining the good basic study habits stated that one must study with the primary intention of understanding. This requires one not to be in a hurry in reading through, instead sustained concentration is necessary. Concentrating on learning requires several useful techniques and tips for helping students to get the best understanding of their course material in order to achieve full competence in the subject and high grades in examination. These methods include critical thinking, metacognition, reading text skills, time management, controlling reading difficulties, index system of study, enhancing memory efficacy, concept mapping and thinking aloud. Conceptually, Oloyede and Olatoye (2005) described study habit as a systematic conscious task of acquiring specific knowledge geared towards a set of standards. Study habits are behaviours directed at effective learning. These behaviours are usually manifested in the learners' response to class work, assignments, reading, note taking, concentration, and time management, consultation with teachers and other learners and tactics used in examination (Umoinyang, 1999). It is the wish of every student to accomplish his or her goals in education. While in school, the goal of students may be to pass a certain number of courses to obtain a degree. For any student to achieve this goal calls for the development of good study habits that will lead him or her to academic success. To develop good study habits is a complex phenomenon. But the basic truth is that effective study skills must be practiced in order to improve academic performance. Proper investment of time in students' life is equally important in education.

Distance Education is a form of education where the student and the instructor are not in the same place (Raghavan, 2009). Instructions may occur through formats such as online instruction, correspondence courses, or television or multimedia packaged formats. As adult learners on the Distance Education programmes, students are mostly challenged by sudden increase in responsibilities, physiological, emotional, psychological and social issues. Schuemer (as cited in Ahiatrogah, Deku \& Dramanu, 2008) observed that many distance education students are older, have jobs and families which influence their studies. They are equally faced with lack of motivational factors of learning such as contact or competition with other students. Distance Education learners, especially the beginners, may have some difficulty determining what the demands of a university study actually are because they do not have the support of an immediate peer group, the instructor, or familiarity with the technology being used for delivery of Distance Education materials. Morgan (1991) noted that those who are not confident about their learning abilities tend to concentrate on memorizing facts in order to complete assignments and write examinations. As a result, they end up with weak grades as a result of poor understanding of materials. The organizers of the Distance Education programme of the University of Cape Coast have clearly spelt out the number of hours students need to spend on each session of their course book. For instance, a three-credit course book of thirty six (36) sessions has been structured to reflect the weekly three-hour lecture for the course in the University. Thus, each session is equivalent to a one-hour lecture on campus. According to the organizers, a distance learner is therefore expected to spend a minimum of three hours and a maximum of five hours on each session in the course book or module. However, distance education students scarcely have much time for self-study because of pressure from their work places, interference from family members, financial constraints as well as other social issues that take chunk of their time. Students of distance education also resort to ineffective study skills which not only lead to poor performance in examination, but also they are unable to develop understanding of the concepts, issues and ideas which also leads to high rate of student drop out. In preparation for examinations, students tend to read their text as if they were novels, apparently ignorant or negligent of the needed skills to study effectively (Nyarko-Sampson, 2004). Some distance learners, for example, study at the comfort of their homes with music and television on, yet according to Turnbull (as cited in Nyarko-Sampson, 2004) music is known to have detrimental effect on recall.

Study habits can be either positive or negative. It is positive when it helps in promoting effective learning and negative when it inhibits learning. Study habit, is a good predictor of learning outcomes in schools (Essuman, 2003; Nyarko-Sampson, 2004; Edusei, 2007; Ahiatrogah, Deku \& Dramanu, 2008; Nonis \& Hudson, 2010) and therefore needs to be researched into. Nonis and Hudson (2010) found that study skills or habits would have a significant direct relationship with the academic performance of college students. Study habits or strategies such as paying attention in class, being on time, taking good notes, completing homework in a timely manner, and reading the study material before a lecture would have a significant direct relationship with the academic performance of college students. Although not every learning strategy or study habit produces useful results in terms of academic achievement, it would be expected that students who possess good study habits in general are better performers than those students with poor study habits. There is some empirical evidence that shows that study habits impact academic performance. Borg, Riding and Falson (1999) and Okpala, Okpala and Ellis (2000) reported that good study strategies positively influenced performance in 
economics courses. Studies conducted in other countries among distance education students on study habits concluded that students of distance education programmes lack good study habits as well as effective study skills (Bunch-Keemer, 2002, Oloyede \& Olatoye, 2005). To achieve successful distance learning, learners need to take their own responsibility for learning (Garrison, 1997). Use of learning strategies (study habits) and maintaining self-motivation are the main elements contributing to distance learners' self-learning (Anderson, 2007). Distance Education learners therefore require the provision of students support services in the form of guidance and counselling to give students individual encouragement, help and guidance to reduce the sense of isolation with which they carry out their studies. Provision of guidance and counselling services will give general guidance and direction to students on effective self-study techniques, time management and other supports as they progress through their studies and see to the overall academic progress and other pertinent issues that affect students' learning.

This study was designed to look at the study habits of distance education learners of University of Cape Coast and how guidance and counselling services can aid their adaptation in psychological, emotional and physical as well as social roles. This is because adult students need effective learning environment, strategies and good study habits to achieve their distinct goals and expectation in education especially persistence in learning. The task of counselling is to give the client an opportunity to explore, discover and clarify ways of living more satisfactory and resourceful lives (Adebayo, 2007). According to Adebayo, counselling occupies a prominent place in the process of leaning and if individual needs are not met through counselling, learning may probably become un-interesting and the concerned student may become disturbed. According to Matemilola (1991), knowing the counselling needs of students can always provide a valid basis for providing the essential guidance service through which students can learn new coping mechanisms or seek help for those problems they cannot handle. Matemilola listed the counselling needs of students to include: overcoming anxieties of finances, developing more positive self-concept, ability to develop effective study habits, ability to combine studies with chores and caring for baby. Counselling is very essential for adult students who need to find themselves by weighing the pros and cons of each need to aid necessary adaptation to their new found role but it is highly neglected. Kerka (2002) maintained that meeting the needs is not a viable guiding principle, at the heart of practice. He stated andragogical methods which purports to provide a relaxed, trusting, mutually, respectful, informed, warm, collaborative, and supporting learning environment are more conclusive to learning at all ages (Wei, Sulaiman, Wardah \& Kassim, 2011). This means that the adult student needs the services of a counsellor to be able to overcome their challenges and also adapt good and favourable learning styles and to develop a good study habits as well.

It is in line with the above discussions that this study sought to examine the study habits of University of Cape Coast Distance Education learners at the Cape Coast Study Centre in the Central Region of Ghana and its implications for counselling. Specifically, the study was designed to seek answers to the following questions:

1. What are the study habits exhibited by distance education students of University Cape Coast at Cape Coast Study Centre?

2. What are the guidance and counselling needs of University of Cape Coast distance education students at Cape Coast Study Centre in relation to their study habits?

\section{Methodology}

\subsection{Research Design}

Descriptive survey was used as a research design to conduct the study. Creswell (2002) perceived descriptive survey to be authoritative and comparatively easy to explain and understand. They allow for standardization and uniformity both in the questions asked, and in the method of approaching subjects, making it easier to compare and contrast answers by respondents' groups. It is in this context that the descriptive design is considered appropriate because this study was designed to describe, analyze, observe and, document to determine the current status of the participants with respect to their study habits at the Cape Coast Study Centre. To reduce response error or bias to the minimum, the essence of the study was thoroughly explained to the respondents. They were allowed to ask questions on what they did not understand, and also call the attention of the researcher to any difficulty they encountered in the course of responding to items or statements on the questionnaire.

\subsection{Population}

The population for the study was students pursuing distance education programmes at the Centre for Continuing Education at Cape Coast Study Centre, with the exception of first year students of both Business and Education 
programmes. From records obtained at the Centre for Continuing Education the population consisted of 2,800 students.

\subsection{Sample and Sampling Techniques}

The sampled population was made up of 338 students who were sampled from Diploma and Post-Diploma of Education Programmes and both Diploma and Post- Diploma in Business Programmes. This decision was informed by Krejcie and Morgan's (1970) table of sample for a study. The choice of respondents from each programme was done using the stratified sampling procedure. The students pursuing various courses at the various levels were stratified into courses strata and a proportional sampling technique was used to select the required number students. The simple random sampling technique specifically the table of random numbers method was used. In using the table of random numbers, attendance registers were collected from the course tutors. A sampling frame which consisted of the names of students on both Education and Business Programmes (excluding first year students) had numbers assigned to the students' names. Appropriate tables of random numbers were selected and numbers were picked from the tables randomly and registered. The names in the sampling frame and its corresponding numbers constituted the sample. The total number of students used for the study was 338 made up of 125 (37\%) females and $213(63 \%)$ males being proportional representation of the total population.

\subsection{Research Instrument}

Questionnaire was the instrument used to collect data for the study. Gay (1992) stated that descriptive survey studies are usually conducted by administering questionnaire. The use of the questionnaire was appropriate because it made it possible for study habits of students pursuing distance education to be scanned. The structure of the questionnaire was made up of only close-ended items. The use of the close-ended format offered the respondents fixed alternative responses. The questionnaire was constructed based on the five-points likert-type scales. The contents of the questionnaire were developed along the line of the research questions formulated for the study. The contents were made up of demographic characteristics of the students, study habits, and guidance and counselling needs of students. Factors that determined or affect study habits of the students were considered when formulating the items. The five thematic areas considered were learning environment, note taking, concentration, time management and guidance and counselling needs. Five questions were set under each thematic area considered with exception of guidance and counselling needs which had 15 questions. The guidance and counselling needs assessed during the study were related to metacognition, self-concept, strategy formation and control strategies. Items were constructed based on five-point likert type scales with the corresponding meaning very true (5), true (4), not sure (3), not true (2) and not at all true (1). In all, the research instrument comprised of 40 questions.

\subsection{Data Collection Procedures}

Permission was sought from the Director, Centre for Continuing Education, University of Cape Coast which provided an explanation of the intent and authenticity of the research and was delivered to the students through the study centre coordinator in order to seek access for the conduct of the study. A follow up visit was made to the students at the study centre to interact with them and to establish rapport for the conduct of the study. In all four weeks were used for distribution and collection of the questionnaires and had a return rate of about 100 percent.

\section{Results and Discussions}

The intent of the study was find out the study habits exhibited by students pursuing distance education at Cape Coast Study Centre. Issues examined include the learning environment, note taking, time management and the concentration level of students. The issues were measured on a discrete five-point scale ranging from one to five where one represents the least agreement to the issues while five represents the highest agreement to the issues. The five-point scale was transformed into three-point scale since discrete figures were used in coding the responses. The combined percentage distributions of the responses are presented in Table 1. 
Table 1: Study Habits Exhibited by Students Pursuing Distance Education at Cape Coast Study Centre

\begin{tabular}{|c|c|c|c|c|c|c|}
\hline \multirow{2}{*}{ Statements } & \multicolumn{2}{|c|}{ True } & \multicolumn{2}{|c|}{ Not Sure } & \multicolumn{2}{|c|}{ Not True } \\
\hline & No. & $\%$ & No. & $\%$ & No. & $\%$ \\
\hline My study room is more spacious with good ventilation. & 213 & 63.1 & 19 & 5.6 & 106 & 31.3 \\
\hline I do not feel comfortable reading in bed. & 152 & 45.0 & 15 & 4.4 & 171 & 50.6 \\
\hline I have a chair and a desk in my study room. & 268 & 79.3 & 7 & 2.1 & 63 & 18.6 \\
\hline I always turn off my TV set when studying. & 79 & 23.4 & 99 & 29.3 & 160 & 47.3 \\
\hline I do not enjoy studying with music. & 124 & 36.7 & 142 & 42.0 & 72 & 21.3 \\
\hline I take down important notes during face to face discussion. & 285 & 84.3 & 30 & 8.9 & 23 & 6.8 \\
\hline I highlight important words or phrases in my book when studying. & 291 & 86.1 & 15 & 4.4 & 32 & 9.5 \\
\hline I am able to study up to three hours or more in a day. & 130 & 38.4 & 27 & 8.0 & 181 & 53.6 \\
\hline I do have a personal study time table. & 217 & 64.2 & 57 & 16.9 & 64 & 18.9 \\
\hline I devout enough time for all my courses. & 154 & 45.6 & 85 & 25.1 & 99 & 29.3 \\
\hline I use my own words when taking down note & 252 & 74.5 & 8 & 2.4 & 78 & 23.1 \\
\hline I do not spend much time on social activities at the expense of my studies. & 156 & 46.2 & 43 & 12.7 & 139 & 41.1 \\
\hline I do not study few hours before examination. & 54 & 15.9 & 32 & 9.5 & 252 & 74.6 \\
\hline I study with my friends but with less verbal conversation. & 53 & 15.7 & 53 & 15.7 & 232 & 68.6 \\
\hline I do not bother myself with personal problems when studying. & 82 & 24.2 & 59 & 17.5 & 197 & 58.3 \\
\hline I never doze off when studying. & 120 & 35.5 & 42 & 12.4 & 176 & 52.1 \\
\hline I am never attracted to the TV set and other family activities when studying. & 100 & 29.6 & 29 & 8.6 & 209 & 61.8 \\
\hline
\end{tabular}

Source: Field Data, 2012.

Table 1 shows that majority (63.1\%) of the respondents had study rooms that were more spacious with good ventilation. This finding of the study agrees with the assertion of Hills and Ballow (2000). Hills and Ballow posited that there is the need for abundance of fresh air in the study environment to avoid unnecessary fatigue. They further pointed out that glaring light could cause eye strain and headaches. Therefore covered light bulbs and light coloured blotters be used if possible to reduce light intensity.

Similarly, 50.6 percent of the respondents stated that they do feel comfortable reading in bed. This contradicts what Osa-Edoh and Alutu (2012) proposed as a good environment for study. They argued that where one studies has an important effect on one's efficiency because the location and its characteristics are stimuli which affect one's studies. The stimulus of the study environment should produce the response of studying and no other response. Reading in bed will only induce the student to sleep. It has been suggested that an important approach is to set aside a special place for study. It should be well ventilated, noise free and well lighted room or open place with a desk and a chair (Ruch, 2005). Again, 79.3 percent of the respondents indicated that they have a chair and a desk in their study room. This outcome of the study is in line with the view of Ruch (2005). According to Ruch, every student must have a chair and a desk for study and that the type of chair and desk used for study by student should be such that it allows the individual to maintain an erect and comfortable sitting posture. The study desk should be spacious enough for the books and materials but should contain only what one needs at a time. However, 47.3 percent of the respondents were of the view that they do not turn off their TV set when studying. Also, 42.0 percent of the respondents were not sure whether they enjoy studying with music whilst 36.7 percent of the respondents admitted that they do not enjoy studying with music. These findings of the study are inconsistent with that of Turnbull (as cited in Nyarko -Sampson, 2004). He reported that music is known to have detrimental effect on recall.

With regard to note taking, Table 1 shows that majority (84.3\%) of the respondents take down important notes during face-to-face discussion. This finding supports the work of Derville (1998) and Kesselman-Turkel and Peterson, (1982). Derville posited that students should learn to take notes irrespective of their reading styles and also read over the notes consistently and regularly. Kesselman-Turkel and Peterson were also of the view that taking notes helps keep you focused on your subject area and to the task at hand. Similarly, 86.1 percent of the respondents admitted that they highlight important words or phrases in their book when studying whilst 74.5 percent were of the view that they use their own words when taking down notes. These results are in line with the views of Okorodudu (2000). Okorodudu emphasised that unless a student has an exceptional memory, it is difficult to master and recall accurately all the main points and relevant details in a study material by merely reading it. Majority (84.0\%) of the respondents were of the view that they do not surf the internet to get additional information regarding the lesson. This indicated that students do not fish for additional information other than what is in their modules. This finding is in disagreement with Nyarko-Sampson's (2004) which indicated that the relevance of motivation as a technique in instruction is not only to sustain the students' 
interest in the lesson but also to provide the impetus for further learning and finding additional materials of the subject even after the lesson. Nyarko-Sampson reiterated further that students are expected not only to rely solely on what the teacher presents in class; the student, he said, is also expected to study additional materials on their own to augment and concretise what they gain in class. This is very true especially in this modern era where information is readily available on the internet for students to surf. Students are expected to make it a habit to surf the internet for additional information to complement what is in their modules. This will in turn broaden and widen students' knowledge and understanding of issues. Again, 78.1 percent of the respondents admitted that they do not read over their notes after every face-to-face meeting. This finding does not agree with the views of Okorodudu (2000). According to Okorodudu, students should read over the notes consistently and regularly. Students take down notes but do not read over them, these notes are useless if they are not reviewed consistently and regularly particularly just before examination. This also confirms the fact that distance education students at University of Cape Coast Study Centre do not make time to read over their notes.

As contained in Table 1, 53.6 percent of the respondents were of the view that they are unable to study up to three hours or more in a day. This is in contradiction with the findings of Freeman and Morss (1993) who believe that for study to be effective, it should be regular, intense and should cover long periods. With reference to this finding, the organizers of the Distance Education programme of the University of Cape Coast have clearly spelt out the number of hours students need to spend on each session of their course books. For instance, a three-credit course book of 36 sessions has been structured to reflect the weekly three-hour lecture for the course in the main University courses. Thus, each session is equivalent to a one-hour lecture on campus. According to the organizers, a distance learner is therefore expected to spend a minimum of three hours and a maximum of five hours on each session in the course book or module. However, 64.2 percent of the respondents admitted that they do have a personal study time table. This result is congruent to the views of Robinson (2000) who asserted that determining time limits for study sets the immediate goal for completing ones work within specific time limits and also helps one to resist recreational distraction. Robinson further posited that students should try to design a personal study time table that will guide them in their private study. Lajoie and Azevedo (2006) also reiterated that students should have personal timetable, and be able to identify peak performance and draw timetable to cover that period. Peak performance is the time you are able to read and concentrate best. Once the time table is drawn it should be followed rigidly and be reviewed intermittently when the need arises.

As presented in Table 1, 45.6 percent of the respondents indicated that they devout enough time for all their courses. Similarly, 46.2 percent of the respondents said they do not spend much time on social activities at the expense of their studies. These findings further confirm the views of Robinson (2000) who said enough time has to be spent on a course work at school. Majority (74.6\%) of the respondents indicated that they do study few hours before examination. This finding is in line with the views of Nyarko-Sampson (2004), who reported that in preparation for examinations, students tend to read their text as if they were novels, apparently ignorant or negligent of the needed skills to study effectively. The above outcome of the study also confirmed the view of Orr (1992), that final examination preparation is often neglected or vigorously repressed by most students during the early weeks of the semester. Few students want to start revising for their examination the following week before the start of the examinations. Rather students are advised to prepare well because examinations count for a very large percentage of their final marks in most subjects. Therefore, it is good to get started early on your revision and learn as the semester progresses. The implication here is that students should not wait for last minute to examination before they hurry through their notes. If this is done it does not only lead to poor performance in examination but, also poor digestion of the material studied.

With regard to concentration as one of the themes under study habits, 68.6 percent of the respondents indicated that it is not true that they study with their friends but with less verbal conversation. This implies that students study with their friends with intermittent conversations which is contrary to the view of Awabil et al (2008). They were of the view that conversation can also distract one's attention which can inhibit concentration. Students should therefore be careful when studying with friends. However, 58.3 percent of the respondents were of the view that it is not true that they do not bother themselves with personal problems when studying. These findings are contrary to the views of Oladele (2000) who suggested that to avoid external distraction, students could choose place of study which can stimulate them to study. The essence of this is that once they are in such environment associated only with study, distraction such as anxiety and indecision, day dreaming, mental and physical fatigue that impair the ability to concentrate will be avoided. Personal problems that keep on flashing to one's mind if not properly tackled and discarded can act as greatest hindrance to concentration. Table 1 further indicated that majority (52.1\%) of the respondents doze off when studying. This according to Oladele (2000) impairs one's ability to concentrate whiles learning. Similarly, 61.8 percent of the respondents said they were attracted to the TV set and other family activities when studying. Logically, this means that students do not have special place for studies. This contradicts the views of Osa-Edoh and Alutu (2012) who were of the view that consideration should be given to the environment in which one studies, as it appears to have adverse effect on the whole 
concept of studying. Where one studies has an important effect on one's efficiency because the location and all its characteristics offer stimuli for studying. The stimulus of the study environment should produce the response of studying and no other response. Such a place should be well ventilated; noise free and well lighted room or open place with a desk and a chair. Awabil et al, (2008) also posited that sound can affect your concentration a great deal. Although many students insist that they can accomplish a lot while TV, radio or CD is playing, scientific studies suggest otherwise. Also, 55.3 percent of the respondents admitted that they clear all other materials from their study table before they begin their studies. These findings are in line with good study habit outlined by most researchers. Awabil et al, (2008) said, the desk should not be full of unwanted materials as this can also inhibit concentration. The desk should have only what one needs at the time of study. The study desk should be spacious enough for the books and materials but should contain only what one needs at a time to ensure concentration.

The next issue the study focused on was the guidance and counselling needs of the University of Cape Coast distance education students studying at Cape Coast Study Centre. Issues considered were time management, team work, study habits and procedures in studying. Other issues examined were concentration, building of self-esteem, drawing of personal time table and building of self-confidence. The percentage distributions of the responses are presented in Table 2.

Table 2: Guidance and Counselling Needs of Students as a Support Service for their Learning at Cape Coast Study Centre

\begin{tabular}{|c|c|c|c|c|c|c|}
\hline \multirow{2}{*}{ Guidance and Counselling Needs } & \multicolumn{2}{|c|}{ True } & \multicolumn{2}{|c|}{ Not Sure } & \multicolumn{2}{|c|}{ Not True } \\
\hline & No. & $\%$ & No. & $\%$ & No. & $\%$ \\
\hline I need guidance and counselling on time management. & 305 & 90.2 & 8 & 2.4 & 25 & 7.4 \\
\hline I need guidance and counselling on how to prioritize my daily activities to enable me study effectively. & 298 & 88.2 & 18 & 5.3 & 22 & 6.5 \\
\hline I need guidance and counselling on writing and answering of examination questions. & 295 & 87.2 & 36 & 10.7 & 7 & 2.1 \\
\hline I need guidance and counselling on consultation to foster team work and improve my studies. & 297 & 87.9 & 29 & 8.6 & 12 & 3.6 \\
\hline I need guidance and counselling on how to develop the skill of effective reading. & 312 & 92.3 & 18 & 5.3 & 8 & 2.4 \\
\hline I need guidance and counselling on $\mathrm{p}$ & 301 & 89.1 & 15 & 4.4 & 22 & 6.5 \\
\hline I need guidance and counselling to be & 297 & 87.9 & 22 & 6.5 & 19 & 5.6 \\
\hline elling on $r$ & 244 & 72.2 & 68 & 20.1 & 26 & 7.7 \\
\hline I need guidance and counselling on how to & 258 & 76.3 & 53 & 15.7 & 27 & 8.0 \\
\hline I need guidance and counselling to build $u$ & 331 & 97.9 & 7 & 2.1 & 0 & 0.0 \\
\hline I need guidance and counselling on how to build my self-confidence & 300 & 88.8 & 23 & 6.8 & 15 & 4.4 \\
\hline I need guidance and counselling on managing my finances so as to stay focus when studying. & 250 & 74.0 & 65 & 19.2 & 23 & 6.8 \\
\hline I need guidance and counselling on how to combine full time job with my academic work. & 303 & 89.6 & 23 & 6.8 & 12 & 3.6 \\
\hline I need guidance and counselling on personal issues that affect my studies. & 308 & 91.1 & 22 & 6.5 & 8 & 2.4 \\
\hline
\end{tabular}

Source: Field Data, 2012.

Table 2 shows that majority, (90.2\%), of the respondents need guidance and counselling on time management. This finding is consistent with the views of Orr (1992) which indicated that studying is a skill and that being successful in school requires a high level of study skills. Students must first learn these skills, practice them and develop effective study habits in order to be successful. According to Orr, good study habits include many different needs such as time management, self-discipline, concentration, memorization, organization and efforts put into the study. Similarly, 88.2 percent of the respondents indicated that they need guidance and counselling on how to prioritize their daily activities to enable them study effectively. This outcome of the study agrees with that of Kerka (2002) that adult students need guidance and counselling to create new and more flexible arrangement that will aid persistence study through prioritization of daily activities, especially with assignments, time spent on work, hobbies, family or friends and also makes decision as to how to manage time well.

Majority (87.2\%) of the respondents admitted that they need guidance and counselling on writing and answering of examination questions. Also, 87.9 percent of the respondents were of the view that they need guidance and counselling on consultations to foster team work and improve their studies. With regard to effective reading, 92.3 percent of the respondents indicated that they need guidance and counselling on how to develop the skill of effective reading. These findings are in line with the view of Kerka (2002). According to Kerka, meeting the needs of students is a viable guiding principle which is at the heart of the practice of learning. Kerka stated that an andragogical method which is purported to provide a relaxed, trusting, mutually, respectful, informed, warm, collaborative and supporting learning environment is that 
which is more conducive to learning at all ages. Kerka further asserted that students must be supported in order for them to foster team work, improve their studies and develop effective reading skills.

In addition, majority (89.1\%) of the respondents indicated that they need guidance and counselling on procedures to study. Similarly, 87.9 percent of the respondents were of the view that they need guidance and counselling to be able to concentrate fully on their studies. Again, 97.9 percent of the respondents stated that they need guidance and counselling on how to build up their self-esteem to achieve academic excellence. These findings are consistent with those of Oduaran (2000) who indicated that counsellors are in service to assist students to cope up with their new psychosocial effects arising from the forces of change, and prepare their mind for the new financial and social problems associated with changes. The preparation of the mind also equips the adult students to develop abilities, interests, aptitudes, self-esteem, and self-fulfillment in making appropriate decisions as to how to study. The result in Table 2 further showed that 72.2 percent of the respondents needed guidance and counselling on how to draw a personal timetable and stick to it. This result confirms that of Lajoie and Azevedo (2006). According to Lajoie and Azevedo, students should have personal timetable and be able to identify peak performance and draw timetable to cover that period. Peak performance is the time you are able to read and concentrate best. Once the time table is drawn it should be followed rigidly and be reviewed intermittently.

As shown in Table 2, majority (76.3\%) of the respondents indicated that they need guidance and counselling on how to stay awake and alert during their study time. Similarly, 88.4 percent of the respondents need guidance and counselling on how to use mnemonics to help them recall what they have studied. These findings are in line with Ogbodo's (2002) recommendation, that students should be guided to devise mnemonics for important ideas, principles, concepts, formulae to help them in their studies. This is to help students' immediate recall and reutilization of ideas, concepts and formulae learnt. Again as presented in Table 2, 88.8 percent of the respondents said they need guidance and counselling on how to build their self-confidence. This finding is consistent with the view of Kerka (2002). According to Kerka, adult students must be helped to adopt behaviours that are positive to the development of attitudes that would help them to build up their self-confidence. Majority (74.0\%) of the respondents also indicated that they need guidance and counselling on managing their finances so as to stay focus when studying.

Table 2 again depicted that 89.6 percent of the respondents said they need guidance and counselling on how to combine full time job with their academic work. This finding confirms the comments made by Ogbodo (2002) that distance learners are likely to adapt the 'Brown' study strategy, since many of them are adult students with full-time jobs, full-time family responsibilities or part-time jobs. The demands of their job, coursework, family responsibilities and other commitment that may make their minds to wander away when they open their books to study. Teachers and school counsellors should watch out for this type of negative study habits among students. Adult students returning from work need to relax their brain before concentration on their reading.

Similarly, 91.1 percent of the respondents indicated that they need guidance and counselling on personal issues that affect their studies. This is in line with the view of Adebayo (2007), who stated that counselling occupies a prominent place in the process of leaning and if individual needs are not met through counselling, learning may probably become un-interesting and the concerned student may become disturbed. Also according to Oladele(2000), personal problems and issues that keep on flashing to one's mind if not properly tackled and discarded can act as greatest hindrance to concentration on students' studies.

\subsection{Conclusions}

Forming study strategies that are effective in learning is a very important step in a student's educational development. In this regard, students must develop various study skills to manage their time and other resources to complete an academic task successfully. Distance Education students at Cape Coast Study Centre were found to exhibit various study habits which are related to their learning environment, learning styles and skills, time management, concentration and note-taking which ranged from moderate to poor study habits. Students who are well guided and counselled are result oriented and thus perform well in tests and examinations. Therefore, assist distance education students as to improve on their performance, it is important that they are provided with guidance and counselling services on their study habits.

\subsection{Recommendations}

From the findings and conclusions drawn, the following recommendations are necessary for the improvement of study habits of distance education students in general and specifically those at the Cape Coast Study Centre. 
1. One of the findings of the study was that most of the study habits exhibited by the students were poor and could lead to poor academic performance. It is recommended that Distance Education students be provided with guidance and counselling services on the formation of good study habits during their orientation programme on the start of their enrolment into the distance education programme.

2. One of the findings from the study was that students spend most of their time on social issues at the expense of their studies. It is therefore recommended that guidance and counselling units should be established in every study centre to offer services to students especially in areas such as time management and prioritization of daily activities.

3. The study revealed that majority of the students do not surf the internet or read other books for additional information. It is therefore recommended that counsellors, regional resident tutors and course tutors encourage students to read wider to broaden their knowledge to gain better understanding of materials provided in their textbooks and other learning materials they are given to study.

\section{References}

Adebayo, O. O. (2007). Problems and counselling needs of sandwich students of University of Illorin, Nigeria. Illorin: Univrsity Press.

Ahiatrogah, P. D., Deku, P., \& Dramanu, B. Y. (2008). The relationship between study habits and academic performance: A case study of University of Cape Coast distance learners. Journal of Educational Development and Practice. 2, 40-53

Anderson, B. (2007). Independent learning, in Moore, M. G. (Ed.) Handbook of distance education. London: Lawrence Erlbaum Associates, Publishers.

Awabil, G., Essuman, J. K., Forde, L. D., Antiri, K. O., Nyarko-Sampson, E.,Turkson, A. B., \& Ocansey, F. (2008). Improving your concentration for studies. Study Guide Monograph Series. 8, 2-20.

Azikiwe, U. (1998). Study approaches of University students. Lagos: WCCl

Bajwa, N., Gujjar, A., Shaheen, G.,\& Ramzan, M. (2011). Study habits of students. International Journal of Business and Social science, $2(14), 175-185$

Borg, M. G., Riding, R. J., \& Falson, J. M. (1999). Towards a model for determination of occupational stress among school teachers. European Journal of Psychology of Education, 6,355-373.

Bunch-Keemer, D. (2002). Create good time management and study habits. Retrieved October 13, 2012, from http://www.unc.edu/depts/unc-caps/Ten/Traps.html

Creswell, J. W. (2002). Educational research: Planning, conducting and evaluating quantities and qualitative research. Upper Saddle River, NJ: Prentice Hall.

Crow, R.D. \& Crow, A. (1992). Educational psychology. New York: American Book Press.

Edusei, C. K. (2007). Validation of the habit survey instrument of University of Cape Coast students: A case of University of Cape Coast. An Unpublished M.Phil Thesis, Cape Coast, University of Cape Coast.

Essuman, J. K. (2003). A study of the study habit and achievement of JHS pupils in Winneba. (Unpublished).

Freeman, V. S., \& Morss, J. (1993). Study habits and academic achievement among Asian students. College Student Journal, 27(3), $352-5$

Garrison, D. R. (1997). Self-directed learning: toward a comprehensive model. Adult Education Quarterly, 48(1), 18-33.

Gay, L. R. (1992). Educational Research: Competenciesfor Analysis and Application. New York: Macmillan.

Hills, P. S., \& Ballow, H. (2000). Effective Study Skill. London: Pan Books

Kerka, S. (2002). Teaching adults is it different? Myths and realities. Retrieved December 15, 2012, from, http://www.eric.ed.gov/ericdocument

Kesselman-Turkel, J., \& Peterson, F. (1982). Note taking made easy. Lincolnwood, IL: Contemporary Books.

Krejcie, R. K., \& Morgan, D. W. (1970). Determining sample size for research activities. Educational and Psychological Measurement, 30,607-610.

Lajoie, S. P., \& Azevedo, R. (2006). Teaching and learning in technology-rich environments. In P. A. Alexander, \& P. H. Winne, (Eds.), Handbook of Educational Psychology. London: Lawrence Erlbaum.

Matemilola, S. (1991). Counselling needs of adult N. C. E. part-time students of the College. Osiele, Abeokuta. Unpublished M. Ed. Project, University of llorin. Nigeria.

Morgan, M. (1991). Research into student learning distance education, Victoria, South Australia.Underdale (ED 342-371).

New Standard Dictionary of Education (2001). Study habits. London: University Press.

Nonis, S. A., \& Hudson, G. I. (2010). Performance of college students: Impact of study time and habits.Journal of Education for Business, 85, 229.

Nyarko-Sampson. E. (2004). Study habits among senior secondary school students in some selected districts Central Region, Ghana. Unpublished M. Phil thesis, University of Cape Coast, Cape Coast.

Oduaran A. B. (2000). Effective of adult learning and teaching. Ibadan: University Press Publishing House

Ogbodo R. O. (2002). Effective study habits and examination guide for students. Abuja: Gracehand Publishers.

Okorodudu, R. I. (2000). Intelligence and learning: Adolescent psychology. Absaka, Nigeria: Delta University Press.

Okpala, A. O., Okpala, C., \& Ellis, R. (2000). Academic efforts and study habits among students in principles of macroeconomics course. 
Journal of Education for Business, 75(4), 219 - 224.

Oladele, J. O. (2000). Fundamentals of psychological foundations of education. Lagos: Johns-Lad Press.

Oloyede, D. O., \& Olatoye, R. A. (2005). Study Habits. Ife Psychologia, 13 (2), 56-63.

Orr, F. (1992). Study skills for successful students. Singapore: Lo. Printing Pte.

Osa-Edoh, G. I., \& Alutu, A.N. G. (2012). A survey of students' study habits in selected secondary schools: Implications for counselling. Journal of Social Sciences, 4(3), 228-234.

Raghavan, C. (2009). Gender issues in counselling and guidance in post primary-education: Advocacy Brief. Retrieved February 15, 2012 from http://www. voced.eduraultd/inc-98.745.

Robinson, F. (2000). Principles and procedures in student counselling. New York: Harper and Row.

Ruch, F. L. (2005). Psychology and life. New York: Scot Freeman.

Sorenson, H. P. (1991). Psychology in education. New York: McGraw Hill.

Umoinyang, I. E. (1999). Students' socio-psychological factors as determinants of achievements in senior secondary schools mathematics. Unpublished Ph.D, dissertation. University of Ibadan, Nigeria.

Wei, L. S., Sulaiman, T. F. T., Wardah, M., \& Kassim, Z. A. (2011). Motivation and study habits of working adults: A case study of masters students in Open University, Malaysia. Pahang: Open University of Malaysia. 